\title{
The Influence Of Listening Habits Of English Songs Toward Vocabulary Mastery
}

\author{
Zulianti \\ MI Ma'arif Magelang \\ zulianti11@yahoo.com
}

\begin{abstract}
The objectives of the study are as follows: (1) to find out the intensity of the students' habit in listening English songs, (2) to find out the students' mastery of English vocabulary, (3) to find out the influences of listening habit of English songs towards vocabulary mastery. This is a descriptive qualitative study. The subjects of study were the third year students of MAN I Temanggung. The result of the research are as follow: (1) the majority of the students' listening habits of English songs is good enough that falls on the scores of $68-83$, (2) the majority of the students' vocabulary mastery is fair that falls on the scores of 65-79, (3) there is a positive influence of listening habits of English songs toward vocabulary mastery.
\end{abstract}

Key Words: Listening habit, English songs, Vocabulary mastery.

\section{Abstract}

The tujuan penelitian ini sebagai berikut: (1) mengetahui intensitas kebiasaan mahasiswa dalam mendengarkan lagu Inggris, (2) mengetahui penguasaan perbendaharaan kata mahasiswa Inggris, (3) mengetahui pengaruh kebiasaan mendengarkan bahasa Inggris lagu dan penguasaan perbendaharaan kata. Ini adalah studi deskriptif-kualitatif. Subyek penelitian ialah siswa kelas III di MAN I Temanggung. Hasil penelitian sebagai berikut (1) sebagian besar swa memiliki tingkat kemampuan mendengarkan lagu berbahasa Inggris dinilai baik dengan skor penilaian 68-83, (2) sebagian besar penguasaan perbendaharaan kata siswa lumayan/agak baik dengan skor penilaian 65-79, (3) terdapat pengaruh positif antara mendengarkan lagu Inggris dengan perbendaharaan kata penguasaan. 
The Influence of Listening Habits of English Songs Toward Vocabulary...

Kata Kunci : Kebiasaan mendengarkan, Lagu berbahasa Inggris, Penguasaan kosa kata.

\section{Introduction}

English is the first foreign language. First of all it is quite clear that nearly all people in the world understand that English as one of the international languages used as a means to exchange, share or transfer information.

In Indonesia, it is regarded very important for the development of science, technology, art and establishing relationship among nations. In order to master it well, people need four skills such as: listening, speaking, reading and writing.

In our country, English is taught from elementary school until university. In elementary school English as elective subject, in Junior and Senior High School as compulsory subject, and in university as language department but also there is as compulsory subject like in other departments. In addition, to learn the language it is not only in formal education, students also learn it in non-formal institutions such as courses which offer the easy ways in mastering English. People can choose one of them that are suitable with their purpose. Although they are learning from different sources, they have same motivation in their learning process that they want to get success on it.

Language learning is the activity for students in their endeavor for acquiring vocabulary and grammar for the purpose of developing and expressing ideas in the target language.

To develop and express their ideas in target language they have to master large vocabularies because it is important for them to master the four English skills (listening, speaking, reading and writing) that need 
them. Tarigan states that the quality of one's language skills depends on the quality and the quantity of the vocabulary mastered (Tarigan, $1989: 2$ ). From the statement above, the writer can conclude that vocabulary mastery is very important for the students to master English skills. So, they focus on their attention first to the vocabulary mastery in their learning process.

The graduates of Senior High School who have been taught English for about 6 years still have difficulties in English because they have low vocabulary mastery.

Learning of vocabulary is not only from text books but it can be learned by other ways such as by listening the songs, especially English. If the students often listen the English songs, they can enrich their vocabularies little by little because they will get many unfamiliar words and if they are interested in those songs they will look for the meaning of those words, and automatically they can increase their vocabularies.

Based on the observation in the classroom of third year students of MAN I Temanggung, the researcher found that students got difficulties in the vocabulary mastery like pronunciation, spelling, meaning and memorize the words, however, they should have good vocabulary mastery.

Realizing this fact, the writer thinks that listening habit of English songs is really good way for students to enrich their vocabularies. They can get those things that they do not get in their classes and text books. It is good for them in their learning process. Their skill will develop better if they also learn about it out of school. Moreover, they can know that English in daily communication is slightly different from that of text books. This fact will open their eyes that they should learn from many different sources if they want to get success in learning it.

Based on those explanations, the writer here is interested in searching the influence of listening habit of English songs toward 
The Influence of Listening Habits of English Songs Toward Vocabulary...

vocabulary mastery.

The objectives of the study are as follows: (1) To find out the intensity of the students' habit in listening English songs. (2) To find out the students' mastery of English vocabulary. (3) To find out the influences of listening habit of English songs vocabulary mastery.

\section{The Definition of Vocabulary}

Vocabulary is the total number of words which makes up the languages. It can be defined, caught as the words we teach in the foreign language (Hornby, 1985:959).

Based on Longman Dictionary of Contemporary English, vocabulary is all the words known to a particular person, the special set of word used in a particular kind of work, business, a list of word, usually in alphabetical order and with explanation of their meaning (Group,1981:112).

In learning vocabulary, it is important for students to understand the meaning of the new language in the communication of meaning. People talk in order to express the meaning of their ideas and thoughts, and they listen in order to discover the meaning of what others say. Without meaning in the spoken and expression can make the others do not understand what they say.

Dupuy and Krashen divide the vocabulary into two kinds, namely receptive vocabulary and productive vocabulary (Brown, 1958 : 370). Finocchiaro suggests that students' vocabulary can be divided into passive and active vocabulary rather than receptive and productive vocabulary (Finocchiaro, 1974 : 87). Haycraft defines receptive or passive vocabularies are words that the student recognize and understand when they occur in a context, but which he can not produce correctly, it means in 
reading or listening. On the other hand, productive or active vocabulary is words which the students understand, can pronounce correctly and use constructively in speaking or writing (Brown:370).

In learning vocabulary to get the appropriate meaning of the words of sentences, the thing that must be considered is sense relation. It is important to distinguish the meaning of individut6al items of what they mean in the real word, their meaning in relation to other words within the vocabulary system of the language (their sense) (McCarthy, $1990: 15-16$ ). Beside that there are many important aspects in learning vocabulary, they are:

1. Word Formation

a. Derivational Affixes

b. Inflectional Affixes

(1) Plural forms, (2)Possessions, (3)Third singular verb maker,

(4)Tense markers, (5)Pronouns

c. Compound

Compound words are the words that consist of two parts that make up one meaning.

d. Blends

Blending is the fusion of two words into one and both have original meanings.

e. Clipped

Clipping is a process in which a word is formed by shortening a larger one.

f. Acronyms

Acronyms are the result of forming a word from the first letters of each word in a phrase. 
The Influence of Listening Habits of English Songs Toward Vocabulary...

\section{g. Coining}

Coining is pure creations of writers, inventors, scientists and others who are in need of a term to express a given meaning or to an item or product.

2. Synonym

3. Antonym

4. Homonym

5. Idioms

Before talking about the relation of listening habits of English songs, of course, we have to know the problem of vocabulary mastery.

Students need a high curiosity and motivation from themselves to learn a foreign language. It is really important for them when they learn it. By having a high curiosity and motivation, they will give more attention in learning English. Nowadays, many teachers of English at high schools face a lot of problem in their learning process in class. For an illustration, in senior high school, although they do not in the beginner again, they are still having difficulties in learning of foreign language because their vocabularies are still limited. Students have difficulties in many aspects of learning process. One of their difficulties is to understand the meaning of new words which they just hear beside in considering the meaning of new words in the text. It happens because they do not have habits in listening of English words. Beside that, because English is different from Indonesian language, in culture, pronunciation, and of course in written. About this case, as quoted by Brown:

In the comparison between native and foreign language lies the key to ease of difficulty in foreign language learning .... Those elements that are similar to (the learners) native language will be 
simple for him and those elements that are different will be difficult. (Brown, 1980:149)

From the above explanation, the writer concludes that meaning of words depends on context of sentences, so the students have difficulties to select the appropriate meaning of words.

The different culture from one country to other country is different and sometimes causes misinterpretation in comprehending the meaning of words and it is called as a communication problem. Some misunderstanding is significant and can be easily ignored. Other conflicts are more serious that they can cause misinterpretation and create persistent and negative attitudes towards the language user.

According to Evelyn Hatch and Cheryl Brown there are five steps for students in learning vocabulary, they are:

1. Encountering new words

The students' strategies here include learning new words by reading books, listening to $\mathrm{TV}$ and radio, and reading newspaper and magazines.

2. Getting the word forms

3. Getting the word meaning

4. Consolidating word form and meaning in memory

5. Using the word (Hatch, 1995:372-39).

According to Colin Rose and Malcolm J. Nicholl, units of music, video, audio, dramatization, picture, games and other technique can create "Comprehensive Theatre-Thinking" (Nicholl : 223-224).

Based on those statements above, the writer concludes learning vocabulary of a language needs more practices and patient. The learners cannot learn it from one source only. They should try many ways that can 
help them in enriching their vocabulary. And the last, people cannot master many vocabularies of a language in a short time.

Based on Oxford Dictionary, song is poem set to music and intended to be song (Hornby,1985:219).

According to Collin FLT, song is a piece of music with words that are sung to the music (Collins,1988:89).

Song is short musical work set to a poetic text, with equal importance given to music and to the words. It is generally performed with instrument accompaniment (1986:1220)

From the definition above, the writer concludes that song is a short metrical composition for singing and it is usually performed with instrumental accompaniment. As the writer stated previously, that song is useful, amusing, and challenging means to improve the mastery of students' vocabulary.

Songs are part of music. Music helps us to focus and on guard, it gives emotional dimension for your new words, and integrates the power of left brain and right brain. Plato says "Music is an education instrument which stronger than other instrument (Malcolm:243)." Music also makes high remember capacity, that make the words are remembered easier. We know that words in a song are easier to remember (Ibid:244). Words those are synchronized with music need little aware effort to learn it, big possibility its matter because they attractively united left brain (words) and right brain (music) activity. We also know that music has great influence in emotional system centers, which also part of spread which strive to longrange memory.

Based on the kinds of vocabulary that have been discussed in the page before, the writer considers that vocabularies that are found in English songs are included into active vocabulary. The vocabularies heard 
in the songs are the vocabularies that people use in their daily speaking and writing. The words like: "Every time I see you in my dream", "She cries in her lonely heart thinking", "Don't leave hanging", "I'm sorry", "I can be perfect", "Did you know you used to be my hero?", "I just want to you know", "I've found a reason for me", "Little by little we gave you everything", and the other words that are familiar with the people in communication. They use the words in their daily life, both in oral and writing communication. The listener will not get a difficulty to understand those words because the speakers or singers on those songs say in an interesting and wonderful intonation, so they will know about how to pronounce the words in a right and good pronunciation. More over, they will learn to determine appropriate meaning of words by see their context. But also they sometimes have difficulties because in English songs there are several funky language such as "wanna". "gonna", "gotta", "coz", "cuz" and my be there are the other words.

\section{Research Method}

\section{Population}

Suharsimi Arikunto states "population is all members of the research subject (Arikunto, 1993:102). The population of this research is the third year students of MAN I Temanggung. They are all students of Language Department consisting 60 person.

\section{Sample}

Sample is the part of the representative of population who are observed (Ibid:104). In this research, the writer takes about 60 students from language class. 
The Influence of Listening Habits of English Songs Toward Vocabulary...

\section{Variable and Indicator}

Variable is the various research subject (Hadi,1990:9).

First variable: Listening habits of English songs.

Second variable: vocabulary mastery

First and second variable can be seen from indicators as follows: (a)Songs are listened, (b)Function of songs, (c) Method that use in listening the songs, (d)Activity when listen the songs, (e)Kinds of vocabulary

\section{Method of Data Collection}

a. Questionnaire and test

Questionnaire is written question which are used to get information from respondent. It is the report of their private or other things they know (Kartono,1990:135). The writer uses questionnaire to know about the students' listening habit of English songs. Beside that, a vocabulary test is administrated to find students' mastery of English songs.

b. Documentation

It is finding data about variables in notes, book transcript, newspaper, magazine, meeting note, agenda and so on (Arikunto:202). This method is used as a technique to find the condition of teachers, officers, students, and location of school.

c. Data Analysis

1. The result of test will be presented in the percentage formula:

$\mathrm{P} \quad=\frac{\sum \mathrm{x}}{\mathrm{N} \cdot 100} \times 100 \%$

Explanation:

$\mathrm{P} \quad=$ the score obtained

$\sum \mathrm{x} \quad=$ the sum of score $\mathrm{X}$

$\mathrm{N} \quad=$ Samples 


$$
\mathrm{P} \quad=\frac{\sum \mathrm{y}}{\mathrm{N} \cdot 100} X 100 \%
$$

Explanation:

$\mathrm{P} \quad=$ the score obtained

$\sum_{\mathrm{y}} \quad=$ the sum of score $\mathrm{y}$

$\mathrm{N} \quad=$ Samples

2. To determine whether there is or not a significant influence of listening habit of English songs toward vocabulary mastery, the writer will use product moment formula as follow:

$$
r x y=\frac{\Sigma x y-\frac{(\Sigma x)(\Sigma y)}{N}}{\sqrt{\left(\Sigma x^{2}-\frac{(\Sigma x)^{2}}{N}\right)\left(\Sigma y^{2}-\frac{(\Sigma y)^{2}}{N}\right)}}(\text { Sudjana, 1989:146) }
$$

Explanation:

$\mathrm{R}=$ correlation coefficient of variable $\mathrm{x}$ and $\mathrm{y}$

$\sum x y=$ the sum of the product multiplying the vocabulary test scores and the questionnaire's scores

$\sum x=$ the sum of vocabulary's score

$\Sigma y \quad=$ the sum of questionnaire's scores

$\sum x^{2}=$ the sum of square of vocabulary test scores

$\Sigma y^{2}=$ the sum of square of questionnaire's test scores

$\left(\sum x^{2}\right)=$ the square of the sum vocabulary test scores

$\left(\Sigma y^{2}\right)=$ the square of the sum questionnaire's test scores

$N \quad=$ the total number of respondent.

\section{Discussion}

After the test had been carried out, the scoring of the test papers 
The Influence of Listening Habits of English Songs Toward Vocabulary...

was conducted. The list of the score of listening habits of English songs was presented in Appendix 4, and the list of the students' vocabulary mastery was presented in Appendix 5.

1. Listening Habits of English Songs

The following table can represent the list of the students' standard scores of the frequency in listening of English songs and their level of frequency in Appendix 4

Table 4.1

Distribution of the Listening Habits of English Songs

\begin{tabular}{|c|c|c|}
\hline Scores & Frequency & Criteria \\
\hline $84-100$ & 12 & Excellent \\
$68-83$ & 43 & Good \\
$52-67$ & 21 & Fair \\
$36-51$ & 2 & Weak \\
\hline
\end{tabular}

It is clearly seen in the table above that out of seventy eight students are twelve students of them were excellent in listening habits of English songs, forty there students were good, twenty one were fair and two students were weak.

2. Students' Vocabulary Mastery

The following table can represent the list of students' vocabulary mastery in Appendix 5.

Table 4.2

Distribution of the Students' Vocabulary Mastery

\begin{tabular}{|c|c|c|}
\hline Scores & Frequency & Criteria \\
\hline $91-100$ & 1 & Excellent \\
\hline
\end{tabular}




\begin{tabular}{|c|c|c|}
\hline $82-90$ & 19 & Good \\
$65-79$ & 40 & Fair \\
$50-64$ & 18 & Weak \\
\hline
\end{tabular}

The table above shows that out of seventy eight students taking part in the vocabulary test, only one student of them got excellent level in acquisition, nineteen students got fair and eighteen students got poor.

3. Correlation Analysis

The purpose of data analysis in this research is to measure the listening habits of English songs and the students' vocabulary mastery of third year students of MAN I Temanggung in the academic year of 2005 - 2006. To measure it, it is important to take the prefatory measurement as follows:

Table 4.3

The Prefatory Table for Compulsion of Coefficient Correlation $X$ and $Y$

\begin{tabular}{|c|c|c|c|c|c|}
\hline NO & $\mathbf{X}$ & $\mathbf{Y}$ & $\mathbf{X 2}$ & $\mathbf{Y 2}$ & $\mathbf{X Y}$ \\
\hline 1 & 70 & 26 & 4900 & 676 & 1820 \\
\hline 2 & 64 & 27 & 4096 & 729 & 1728 \\
\hline 3 & 69 & 25 & 4761 & 625 & 1725 \\
\hline 4 & 78 & 28 & 6084 & 784 & 2184 \\
\hline 5 & 74 & 25 & 5476 & 625 & 1850 \\
\hline 6 & 74 & 25 & 5476 & 625 & 1850 \\
\hline 7 & 84 & 31 & 7056 & 961 & 2604 \\
\hline 8 & 95 & 25 & 9025 & 625 & 2375 \\
\hline 9 & 81 & 25 & 6561 & 625 & 2025 \\
\hline 10 & 89 & 32 & 7921 & 1024 & 2848 \\
\hline 11 & 62 & 27 & 3844 & 729 & 1674 \\
\hline 12 & 61 & 25 & 3721 & 625 & 1525 \\
\hline 13 & 81 & 25 & 6561 & 625 & 2025 \\
\hline 14 & 67 & 30 & 4489 & 900 & 2010 \\
\hline 15 & 55 & 25 & 3025 & 625 & 1375 \\
\hline 16 & 57 & 26 & 3249 & 676 & 1482 \\
\hline
\end{tabular}


The Influence of Listening Habits of English Songs Toward Vocabulary...

\begin{tabular}{|c|c|c|c|c|c|}
\hline 17 & 78 & 35 & 6084 & 1225 & 2730 \\
\hline 18 & 79 & 37 & 6241 & 1369 & 2923 \\
\hline 19 & 71 & 27 & 5041 & 729 & 1917 \\
\hline 20 & 78 & 32 & 6084 & 1024 & 2496 \\
\hline 21 & 84 & 33 & 7056 & 1089 & 2772 \\
\hline 22 & 81 & 34 & 6561 & 1156 & 2754 \\
\hline 23 & 79 & 25 & 6241 & 625 & 1975 \\
\hline 24 & 60 & 28 & 3600 & 784 & 1680 \\
\hline 25 & 81 & 26 & 6561 & 676 & 2106 \\
\hline 26 & 67 & 25 & 4489 & 625 & 1675 \\
\hline 27 & 74 & 28 & 5476 & 784 & 2072 \\
\hline 28 & 58 & 33 & 3364 & 1089 & 1914 \\
\hline 29 & 75 & 28 & 5625 & 784 & 2100 \\
\hline 30 & 70 & 29 & 4900 & 841 & 2030 \\
\hline 31 & 85 & 25 & 7225 & 625 & 2125 \\
\hline 32 & 81 & 27 & 6561 & 729 & 2187 \\
\hline 33 & 86 & 27 & 7396 & 729 & 2322 \\
\hline 34 & 80 & 29 & 6400 & 841 & 2320 \\
\hline 35 & 81 & 28 & 6561 & 784 & 2268 \\
\hline 36 & 93 & 26 & 8649 & 676 & 2418 \\
\hline 37 & 73 & 26 & 5329 & 676 & 1898 \\
\hline 38 & 80 & 27 & 6400 & 729 & 2160 \\
\hline 39 & 53 & 27 & 2809 & 729 & 1431 \\
\hline 40 & 71 & 26 & 5041 & 676 & 1846 \\
\hline 41 & 48 & 25 & 2304 & 625 & 1200 \\
\hline 42 & 90 & 30 & 8100 & 900 & 2700 \\
\hline 43 & 62 & 25 & 3844 & 625 & 1550 \\
\hline 44 & 86 & 25 & 7396 & 625 & 2150 \\
\hline 45 & 63 & 26 & 3969 & 676 & 1638 \\
\hline 46 & 69 & 31 & 4761 & 961 & 2139 \\
\hline 47 & 78 & 36 & 6084 & 1296 & 2808 \\
\hline 48 & 84 & 30 & 7056 & 900 & 2520 \\
\hline 49 & 64 & 32 & 4096 & 1024 & 2048 \\
\hline 50 & 74 & 35 & 5476 & 1225 & 2590 \\
\hline 51 & 53 & 30 & 2809 & 900 & 1590 \\
\hline 52 & 63 & 32 & 3969 & 1024 & 2016 \\
\hline 53 & 67 & 25 & 4489 & 625 & 1675 \\
\hline 54 & 72 & 34 & 5184 & 1156 & 2448 \\
\hline 55 & 84 & 34 & 7056 & 1156 & 2448 \\
\hline 56 & 87 & 30 & 7569 & 900 & 2610 \\
\hline
\end{tabular}




\begin{tabular}{|c|c|c|c|c|c|}
\hline 57 & 63 & 33 & 3969 & 1089 & 2079 \\
\hline 58 & 72 & 35 & 5184 & 1225 & 2520 \\
\hline 59 & 73 & 35 & 5329 & 1225 & 2555 \\
\hline 60 & 74 & 33 & 5476 & 1089 & 2442 \\
\hline 61 & 75 & 30 & 5625 & 900 & 2250 \\
\hline 62 & 80 & 31 & 6400 & 961 & 2480 \\
\hline 63 & 74 & 34 & 5476 & 1156 & 2516 \\
\hline 64 & 83 & 35 & 6889 & 1225 & 2905 \\
\hline 65 & 67 & 31 & 4489 & 961 & 2077 \\
\hline 66 & 70 & 25 & 4900 & 625 & 1750 \\
\hline 67 & 51 & 26 & 2601 & 676 & 1326 \\
\hline 68 & 68 & 25 & 4624 & 625 & 1700 \\
\hline 69 & 75 & 27 & 5625 & 729 & 2025 \\
\hline 70 & 66 & 26 & 4356 & 676 & 1716 \\
\hline 71 & 61 & 26 & 3721 & 676 & 1716 \\
\hline 72 & 76 & 25 & 5776 & 625 & 1900 \\
\hline 73 & 81 & 28 & 6561 & 784 & 2268 \\
\hline 74 & 75 & 26 & 5625 & 676 & 1950 \\
\hline 75 & 68 & 26 & 4624 & 676 & 1768 \\
\hline 76 & 70 & 27 & 4900 & 729 & 1890 \\
\hline 77 & 68 & 26 & 4624 & 676 & 1768 \\
\hline 78 & 64 & 32 & 4096 & 1024 & 2048 \\
\hline & $\mathbf{5 6 7 7}$ & $\mathbf{2 1 7 9}$ & $\mathbf{4 2 0 9 7 7}$ & $\mathbf{6 2 7 8 0}$ & $\mathbf{1 6 0 3 9 0}$ \\
\hline
\end{tabular}

The interpret the research finding, the researcher uses the arithmetical calculation and product moment correlation formula to compute the data that has been contained as foll ows:

1). Arithmetical Calculation

a. Calculating the score of students' listening habits of English songs

$$
\begin{aligned}
\mathrm{P} & =\frac{\Sigma \mathrm{X}}{\mathrm{N} .100} \times 100 \% \\
& =\frac{5677}{78.100} \times 100 \% \\
& =\frac{5677}{7800} \times 100 \% \\
& =72,78 \%
\end{aligned}
$$


The Influence of Listening Habits of English Songs Toward Vocabulary...

b. Calculating the score of Students' Vocabulary Mastery

$$
\begin{aligned}
\mathrm{P} & =\frac{\sum y}{\mathrm{~N} .100} \times 100 \% \\
& =\frac{2179}{78.100} \times 100 \% \\
& =\frac{2179}{7800} \times 100 \% \\
& =27,94 \%
\end{aligned}
$$

2). Product Moment Correlation Analysis

$$
\begin{aligned}
\operatorname{rxy} & =\frac{\sum x y-\frac{\left(\sum x\right)\left(\sum y\right)}{N}}{\sqrt{\left(\sum x^{2}-\frac{\left(\sum x\right)^{2}}{N}\right)\left(\sum y^{2}-\frac{\left(\sum y\right)^{2}}{N}\right)}} \\
& =\frac{160390-\frac{(5677)(2179)}{78}}{\sqrt{\left(420977-\frac{(5677)^{2}}{78}\right)\left(62780-\frac{(2179)^{2}}{78}\right)}} \\
= & \frac{160390-158592,09}{\sqrt{(420977-413183,71)(62780-60872,34)}} \\
= & \frac{1797,91}{\sqrt{(7793,3)(1907,68)}} \\
= & \frac{1797,91}{3855,79} \\
= & 0,466
\end{aligned}
$$

From the computation above, it was obtained that $\mathrm{r}_{\mathrm{xy}}=0,466$ and then $r_{x y}$ is consulted to the critical value for $r$ table of product moment to examine whether $r_{x y}$ value is significant or not. The value of $r$ table with $\mathrm{N}=75$ and the $5 \%$ significant level is 0,277 . So, it can be concluded that $\mathrm{r}_{\mathrm{xy}}$ is greater than $r$ table or 0,466 is greater than 0,277 .

The research finding indicate that there is a significant correlation between listening habits of English songs and students' vocabulary 
mastery. These facts imply that listening habits and the frequency in English songs give a useful contribution to enrich students' vocabulary mastery.

Based on the result of the study, we know that listening habits and the frequency in English songs give a useful contribution to enrich students' vocabulary mastery is fall on the good and fair criteria.

This implies that both of the teacher and students must pay attention to them. One way which can be taken by the teacher if he was to point students vocabulary mastery, the frequency of students' listening habits of English songs must be increased and when the teacher teaches language he can use English songs as medium of teaching, especially in vocabulary subject.

\section{Conclusion}

The result of the research are as follow: (1) The majority of the students' listening habits of English songs is good that falls on the scores of 68-83. (2) The majority of the students' vocabulary mastery is fair that falls on the scores of 65-79. (3) There is a positive influence of listening habits of English songs toward vocabulary mastery.

\section{References}

Arikunto, Suharsimi. 1993. Prosedur Penelitian Suatu Pendekatan Praktek. Yogyakarta : Rineka Cipta.

Brown, Douglas. 1980. Principle of language Learning. New Jersey : Prentice Hall.

Collins. 1988. English Language Teaching.

Encyclopedia Americana,vol.25, 1988. 
The Influence of Listening Habits of English Songs Toward Vocabulary...

Finnochiaro, Marry. 1974. The Foreign Language Learner, A Guide for Teacher. New York : . Regents Publising Company.

Hatch, Evelyn, and Brown, Cheryl.1958. Vocabulary, Semantics and Language. California : Cambridge University Perss.

Hornby. 1981. Oxford Advanced Learners Dictionary of Current English, London : Oxford University.

Kartono, Kartini. 1990. Metodologi Riset Sosial, Bandung : Manar Maju.

Longman. 1981. Longman Dictionary of Contemporary English. Great Britain : Pitman Perss.

McCharty, Michael. 1990. Vocabulary, Oxford University Press.

Rose, Colin and J. Nicholl, Malcolm. Accelerated Learning for the $21^{\text {st }}$ Century. Nuansa.

Sudjana, Nana.1989.Tuntunan Penyusunan Karya Ilmiah. Bandung : Sinar Baru.

Tarigan, Henri Guntur. 1989. Pengajaran Kosa Kata, Angkasa, Bandung. 